\title{
MICROSTRUCTURAL CHARACTERIZATION AND EVALUATION OF CERTAIN IMPORTANT PHYSICAL PROPERTIES OF THUJA BURL WOOD
}

\author{
S.R. Shukla ${ }^{1, \star}$, D.P. Kamdem ${ }^{2}$
}

\begin{abstract}
This investigation aimed to characterize certain important anatomical, chemical and physical properties of Tetraclinis articulate (Thuja) burl wood from Morocco. Anatomical properties and constituent structure were analysed using image analysis system, environmental scanning electron microscope (ESEM) and powder x-ray diffraction techniques. A few important physical properties of Thuja burl wood such as density, specific gravity, equilibrium moisture content (EMC), total swelling and water absorption characteristics were evaluated. Real-time water absorption and swelling profiles were recorded electronically using a digital force sensor and linear variable differential transformers (LVDTs) respectively. Microscopic structure observed on fractured surfaces showed very compact and thread-like fibers. Average crystallinity index and diameter of cellulose crystallite was found to be $0,35 \pm 0,03$ and $36 \pm 5,58 \AA$ respectively. The average values of air-dry density and the EMC of Thuja burl wood were $932,67 \pm 50,57 \mathrm{~kg} / \mathrm{m}^{3}$ and $10,19 \pm 1,43 \%$ respectively. Swelling profile as a function of the water immersion duration followed a curvilinear variation with maximum swelling coefficient of $2,9 \pm 0,43 \%$ after 24 hour from oven-dry condition. The suitability of this wood for decorative and handicraft items is attributed mainly to its dense microstructure, higher dimensional stability, lower water absorption, random grain texture, dark brownish with intense and pleasant smell.
\end{abstract}

Keywords: Crystallinity, density, dimensional stability, swelling, Thuja.

\section{INTRODUCTION}

Small, uncontrolled, irregular or spherical extra growths occasionally occurring on the trees near ground level are called burls. The structure of burl wood is generally characterized by eye-like markings surrounded by distorted soft, "velvet-like" and swirls tissues (Beals and Davis 1977). Tetraclinis articulata is an evergreen conifer tree from the Cupressaceae family with the ability to develop burls generally found under the collar of tree. Being native to North-Western Africa and endemic to SouthWestern coast of the Mediterranean Sea, this species is mostly abundant in Morocco and North Africa and commonly known as Thuja, thuya, sandarac or Arar (Ibaez et al. 1989, Hatimi 1994, Moussaouiti et al. 2010, Sanchez-Gomez et al. 2013). Other than Thuja, such wood burls are also found to occur on walnut, maple, redwood just to mention a few. Lansing, USA.

${ }^{2}$ Present address: Institute of Wood Science and Technology, Malleswaram, Bengaluru, India.

School of Packaging, Michigan State University, East Lansing, USA.

^Corresponding author: srshukla@icfre.org

Received: 05.06.2017 Accepted: 30.11.2017 
Thuja burls are composed of mostly light and dark brown bands of high density woody tissues having random grain orientation and distinctive pleasant smell (Kaiser 1997, Moussaouiti et al. 2010, Mouridi et al. 2011a, Mouridi et al. 2011b). Thuja burl wood is in great demand by the artisans due to its peculiar beauty, attractive grain patterns, texture, bands, etc. Since sometime, Thuja burl wood has become a preferred material for artistic handicraft items in artisanal sector of Morocco due to its high aesthetic values. Generally stains are not used while processing and coloured of the finished articles remains very natural. Additionally, Thuja burl wood is aromatic with an incredibly pleasing scent and also oily in touch. Its natural beauty is enhanced and preserved by hand-rubbed finishing process. It is mostly used for decorative objects, turned articles, small furniture, beautiful carvings on boxes of different shapes and sizes and many other interesting objects of high economical value. This type of wood is also very popular among marquetry artisans and cabinet makers. Attractive and unique designs of burl wood products blend well in almost any type of decor and generally treasured for life-time.

Detailed knowledge of anatomical microstructure, quality parameters, processing characteristics as well as biological resistance against decaying agencies of wood material is very important for its efficient utilization and marketing in various high value-added applications. Although, Thuja burl wood is traditionally being used for many applications, limited scientific data is reported in the open literature on the anatomy and various other properties. Recently, the drying behaviour, material symmetries and certain strength parameters such as stiffness measured using non-destructive ultrasonic technique were reported by Mouridi et al. 2011a, Mouridi et al. 2011b). This study was performed to improve the industrial machinability and processing characteristics of Thuja burl wood. Similarly, El Alami et al. (2013) studied the fracture energy of wood from stem or branch as well as burl wood from root of Tetraclinis articulata and found that Thuja burl wood from root was more resistant than wood from stem to crack propagation in the tangential plane. In addition, Thuja burl from root displayed a high degree of variability in the density and fracture energy than Thuja wood. The difference was attributed to the presence of different outgrowth concentrations between the lower and upper parts of the burl. Moussaouiti et al. (2010) analysed the antibacterial activities of essential oil from Thuja burl wood and reported its high potential to control some microorganism growth including bacteria. Bouhtoury-Charrier et al. (2009) also studied and reported biocidal activities of Thuja wood. Presence of extractable compounds called was found to exhibit anti-fungus behaviour and to provide natural long-term durability to Thuja wood against attack from wood-destroying bio-organisms.

The main objective of the present study was to characterize the structural morphology and to evaluate certain important physical and chemical properties of Thuja burl wood grown in Morocco forests in order to improve its utilization as raw materials for the manufacture of high value products. Detailed microstructural investigations were carried out using optical image analysis system as well as environmental scanning electron microscope (ESEM). The measurements of crystallinity index, diameter of cellulose micro-crystallites and physical parameters were performed to understand various features, some machining challenges and dimensional stability reported by wood artisans currently using Thuja wood. The information generated in the present study will be useful to better understand behaviour of Thuja burl wood and improve the utilization of this precious and unique material for various aesthetic, decorative and useful items.

\section{MATERIALS AND METHODS}

Five Tetraclinis articulate (Vahl) Masters, Thuja burl wood samples were collected from representative trees of about 55-60 year-old grown in the forests near Essaouira, Morocco. About 14$15 \mathrm{~mm}$ thick wood plates of different sizes were sawn from these burl samples using a band saw. These plate-shaped samples were conditioned for 60 days in a room maintained at $21 \pm 2^{\circ} \mathrm{C}$ temperature and $60 \pm 5 \%$ relative humidity $(\mathrm{RH})$ until constant weight within $\pm 2 \%$ variation before further testing (ASTM 2008). More than 60 small specimens were prepared from these plates. Dimensions of visually defect free specimens selected randomly for testing of various physical and microstructural properties were $13,6 \pm 0,2 \mathrm{~mm}$ thick by $25,5 \pm 0,3 \mathrm{~mm}$ width and $25,6 \pm 0,3 \mathrm{~mm}$ length. Structural and chemical characteristics using $\mathrm{x}$-ray diffraction (XRD) and physical properties such as equilibrium moisture content (EMC), density, specific gravity, water absorption and swelling profiles were evaluated and 
analysed for numerous specimens as described below.

Small sample blocks of Thuja burl wood were boiled in water for an hour before slicing thin sections of about 15-20 $\mu \mathrm{m}$ (thickness) using a Reichert sliding microtome. These sections were mounted onto glass slides and morphological observations were made using Leica Laburlux microscope connected to image analysis system (Quantimet $500 \mathrm{MC}$ ). Part of remaining burl wood samples was also macerated to obtain individual wood elements. Small burl wood pieces were placed in a test tube and boiled to drive out the air. After decanting the water, nitric acid $30 \%$ and a pinch of Potassium chlorate $\left(\mathrm{KClO}_{3}\right)$ were added and heated in a water bath until almost colourless liquid. The solution was then decanted and washed thoroughly with distilled water to remove traces of acid. The macerated material was gently shaken in water to separate the individual elements. About 30 cells were randomly selected to measure tracheid length, diameter and lumen diameter. Cell wall thickness was calculated by subtracting the lumen diameter from cell overall diameter. Further, ultrafine microstructure of burl wood was investigated at higher magnifications using an environmental scanning electron microscope (PhilipsElectroscan, Model 2020 ESEM). Small moisture free fractured burl wood samples were coated with very thin gold layer. The detailed surface microstructure was examined and various anatomical features were recorded.

The X-ray diffraction spectra of burl wood powder obtained separately from five specimens were measured on a Rigaku Rotaflex 200B diffractometer equipped with $\mathrm{CuK}_{\alpha} \mathrm{X}$-ray radiation and a curved crystal graphite monochromator operating at anode voltage and current of $45 \mathrm{kV}$ and 100 $\mathrm{mA}$ respectively. Peak intensities were obtained by counting with the NaI Scintillation detector every $0,02^{\circ}$ at sweep rates of $1^{\circ} 2 \theta / \mathrm{min}$ and total scan ranged from $5^{\circ}$ to $65^{\circ}$. Thuja burl wood blocks were ground and passed through a standard 40 mesh (average size of about $420 \mu \mathrm{m}$ ). The wood powder samples were placed in silicon sample holder designed for low background and vertical placement. The powder samples were tightly packed to prevent solid loss during collection of XRD. No background correction was applied to the raw data. The crystallinity index $\left(\mathrm{C}_{\mathrm{r}} \mathrm{I}\right)$ of the cellulose and the diameter of the cellulose crystallites (L) in Thuja burl wood were computed from the X-ray diffractograms using following equations (Segal 1959, Wellwood et al. 1975, Navi and Sandberg 2012).

$$
\begin{aligned}
& C_{r} I=\frac{I_{002}-I_{A M}}{I_{002}} \\
& L=\frac{0,9 \lambda}{H \cos \theta}
\end{aligned}
$$

where $\mathrm{I}_{002}$ is the maximum intensity of diffraction peak of the (002) plane, intensity from the amorphous phase of sample, $\lambda$ the wavelength of the diffracting beam (line $\mathrm{CuK}_{\alpha}$ ), $\mathrm{H}$ the width at half height of (002) peak and $\theta$ the angle of diffraction of the (002) peak.

The equilibrium moisture content of burl wood specimens was measured by using an oven-dry method. A total of 30 well-conditioned small blocks of wood specimens with dimensions of $14 \times 25 \times 25$ $\mathrm{mm}^{3}$ were selected and used for the determination of EMC. The specimens were weighed with an accuracy of $0,001 \mathrm{~g}$ in a weighing balance and then dried slowly in a well ventilated hot air oven at temperature of $103 \pm 2^{\circ} \mathrm{C}$ for about 24 hours. The so oven dried specimens were cooled over dehydrated Phosphorus pentoxide $\left(\mathrm{PO}_{5}\right)$ in a desiccator and then weighted. The specimens were dried again in the oven and final weight of each specimen was taken and recorded as oven-dry weight when difference between last two weighs did not exceed $0,002 \mathrm{~g}$. Loss in weight expressed as percentage of oven-dry weight was taken as EMC computed using the following Equation 3:

$$
\operatorname{EMC}(\%)=\frac{W_{1}-W_{0}}{W_{0}} \times 100
$$


where $\mathrm{W}_{1}$ is the weight of conditioned specimen $(\mathrm{kg})$ while $\mathrm{W}_{0}$ is the oven-dry weight of the specimen $(\mathrm{kg})$.

A total of 30 conditioned burl wood specimens measuring $14 \times 25 \times 25 \mathrm{~mm}^{3}$ were selected and used for the determination of the density and specific gravity. Weight and dimensions of each specimen were recorded and volume computed from dimensions. All the specimens were oven-dried at $103 \pm 2^{\circ} \mathrm{C}$ for more than 24 hours to constant weight and oven-dry weight of each specimen was recorded (ASTM 2008). Burl wood density (at EMC) and specific gravity (SG) values were determined using following Equation $4 \mathrm{a}$ and Equation $4 \mathrm{~b}$ :

$$
\begin{aligned}
& \text { Density }=\frac{W_{1}}{V_{1}} \\
& S G=\frac{W_{0}}{V_{1}}
\end{aligned}
$$

$\mathrm{V}_{1}$ is the volume of specimen at test conditions (1) in $\mathrm{m}^{3}$.

Measurements of water absorption (WA) profiles were performed using a digital force sensor from Mecmesin Inc. USA (Model AFG 2.5N). A total of 10 burl wood specimens measuring $14 \times 25 \times 25 \mathrm{~mm}^{3}$ were selected and their initial weights recorded. The force sensor was connected to a computer through hook connected to a force sensor in a plastic container which was filled slowly with distilled water at $22 \pm 2^{\circ} \mathrm{C}$ temperature (Viiri and Tyrvainen 1999). The burl wood specimen was immerged about $25 \mathrm{~mm}$ from the water surface using a small cubic aluminium block of known weight and volume suspended with the same string below burl wood block. The buoyancy forces exerted by the wood specimen and aluminium block were taken into consideration while computing the amount of water absorption by the wood. The weight measurements were taken with an accuracy of $\pm 0,05 \mathrm{gf}$. The weight gain due to water absorption was recorded initially at every second and subsequently at longer intervals. The WA of Thuja burl wood was computed using Equation (5) and profile was plotted as percentage of water absorbed by a specimen in a given time period versus immersion time duration. The percent of the total WA was computed from the weight of the burl wood specimen measured after 24 hours of water immersion.

$$
W A(\%)=\frac{W_{1}(t)-W_{0}}{W_{0}} \times 100
$$

where $W_{1}$ is the weight of the burl wood specimen after water absorption after a given time interval and $W_{0}$ is the oven-dry weight of same specimen.

A total of about 15 burl wood specimens measuring about $14 \times 25 \times 25 \mathrm{~mm}^{3}$ were selected and used to measure the swelling profiles in water. The real-time swelling profiles were recorded electronically for a period of about 24 hours water immersion using three linear variable differential transducers (LVDTs) connected to an in-house designed swell-o-meter (Shukla and Kamdem 2010a, Shukla and Kamdem 2010b). The burl wood specimens were placed on a small metal block kept in separate plastic containers in close contact with the tip of a pre-calibrated LVDTs connected to a computer through a data-logger for real-time display of swelling profiles. DI water was filled slowly in the container and water temperature was kept constant at $22 \pm 3^{\circ} \mathrm{C}$. The swelling profile of each burl wood specimen was automatically recorded in real-time after fixed time intervals by the upward movement of LVDT shaft with an accuracy of $\pm 2,5 \mu \mathrm{m}$. A pre-determined calibration factor was used to convert the electrical signal throughput generated by the LVDTs during swelling to the amount of dimensional change of the specimen. Swelling was measured in two different directions: ends- across smaller dimensions (14 $\mathrm{mm})$ apparently in longitudinal direction, sides- across larger dimensions $(25 \mathrm{~mm})$ apparently in radial and tangential directions and average values are reported. The percentage of swelling (S) was computed from the following Equation 6: 


$$
S(\%)=\frac{T_{1}(t)-T_{0}}{T_{0}} \times 100
$$

where $T_{0}$ is initial thickness of oven-dried burl wood specimen between metal block and tip of LVDT while $T_{1}$ is the thickness of same specimen at any given time during water soaked condition. The maximum swelling values were computed as swelling (in percentage) after 24 hours of water immersion with respect to dry (conditioned) as well as oven-dry conditions.

\section{RESULTS AND DISCUSSION}

Thuja burl wood visually exhibit irregular and spherical growths characterized by eye-like markings surrounded by swirls and distorted tissues. These "eyes" were generally scattered throughout the burl wood. The burl wood was commonly composed of light and dark bands of high density woody tissues with random orientation showing distinct dark brown with random grain texture. No change was noticed due to water soluble extractives after soaking the small wood blocks in distilled water at room temperature for sufficiently long time. The burl wood was also found to be hard and very heavy. The wood was oily and aromatic with pleasing smell. Thuja burl wood is in huge demand and often highly prized by wood turners and craftsmen, because of highly unusual, unique beautiful grain patterns, appealing aesthetic dark brownish colour, and pleasant smell.

Anatomical microstructure and tracheids in the macerated material of Thuja burl wood are shown in Figure 1a and Figure 1b respectively. Certain important anatomical parameters of Thuja burl wood are listed in Table 1. Average values of tracheid length, tracheid diameter and lumen diameter were found to be $1536,88 \pm 26,40 \mu \mathrm{m} ; 30,49 \pm 3,60 \mu \mathrm{m}$ and $20,40 \pm 3,10 \mu \mathrm{m}$ respectively. Earlywood tracheids were observed to be square or rectangular in shape. The latewood is found to be not conspicuous and made up of relatively narrow band of thick walled cells. Tracheids were arranged in more or less definite radial rows. Rays were seen to be narrow, far apart and uniseriate. Axial parenchyma was also observed to be present, diffuse and abundant.
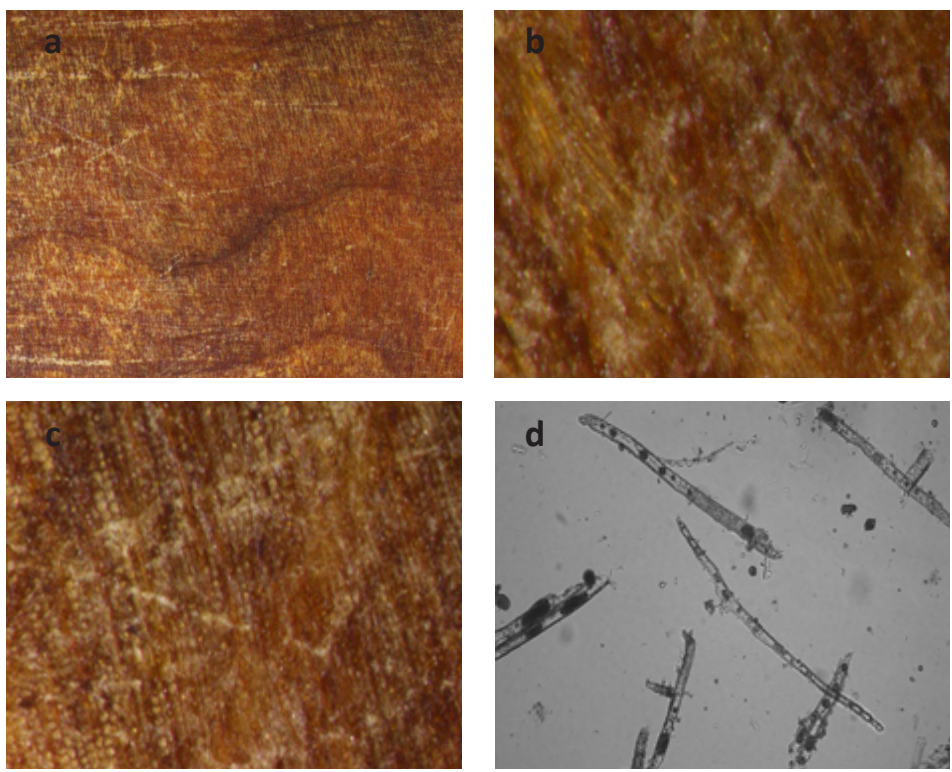

Figure 1. (a-c) Anatomical microstructure and (d) tracheids in macerated Thuja burl wood. 
Under ESEM ( environmental scanning microscope, Thuja wood have thick walled tracheids, cell lumens with pit in the cell wall. Some of the cell lumens were found to be blocked. However, resin canals could not be observed in these wood samples. Recently, Esteban et al. (2015) also reported wood anatomy of Tetraclinis articulata grown in its natural distribution area in Spain and found certain characteristic features such as axial tracheids without helical thickening, low homogeneous rays, cupressoid pits and absence of normal axial traumatic resin canals. However, traumatic axial resin canals were observed in Thuja wood by the researchers supporting occurrence of this feature outside the Pinaceae (Esteban et al. 2015).

Table 1. Average, minimum and maximum values of certain anatomical parameters of Thuja burl wood.

\begin{tabular}{|l|l|l|l|l|}
\hline Anatomical parameters & \multicolumn{1}{|c|}{$\begin{array}{c}\text { Average } \\
\text { Value }\end{array}$} & $\begin{array}{c}\text { Standard } \\
\text { Deviation }\end{array}$ & \multicolumn{1}{|c|}{$\begin{array}{c}\text { Minimum } \\
\text { Value }\end{array}$} & \multicolumn{1}{|c|}{$\begin{array}{c}\text { Maximum } \\
\text { Value }\end{array}$} \\
\hline Tracheid length $(\mu \mathrm{m})$ & 1536,88 & 26,40 & 1371,19 & 1808,22 \\
\hline Tracheid diameter $(\mu \mathrm{m})$ & 30,49 & 3,60 & 23,68 & 39,24 \\
\hline Cell wall thickness $(\mu \mathrm{m})$ & 10,09 & 1,61 & 7,44 & 13,19 \\
\hline Cell lumen diameter $(\mu \mathrm{m})$ & 20,40 & 3,10 & 14,89 & 28,41 \\
\hline
\end{tabular}

Figure 2 shows the x-ray diffraction spectra of Thuja burl wood powder. The crystallinity index for cellulose of Thuja burl wood was computed from X-ray diffractogram using Equation (1) and the average value was found to be $0,35 \pm 0,03$ with $8,4 \%$ coefficient of variation (COV). Similarly, the average diameter of the crystallite (L) of Thuja burl wood was calculated using Equation (2) as $36 \pm 5,58 \AA$ (COV=15,5\%). Four different analysis techniques involving X-ray diffraction for computing $\mathrm{C}_{\mathrm{r}} \mathrm{I}$ of one type of cellulose were compared and found to vary significantly from $39 \%$ to $67 \%$, depending on the technique used in the measurements methods (Thygesen et al. 2005). Andersson et al (2003), Andersson et al (2004) of wood and thickness of cellulose crystallites in early wood of Norway spruce (Picea abies) and Scots pine (Pinus sylvestris). The crystallinity of mature wood was found be about $30 \pm 4 \%$ in both species. The average thickness of the cellulose crystallites was reported as $32 \pm 1 \AA$ and $31 \pm 1 \AA$ for Norway spruce and Scots pine, respectively. Howell et al. (2007) reported the percent crystallinity between $37,0 \%( \pm 0,7)$ and $41,5 \%$ $( \pm 1,1)$ and crystallite width was $33 \pm 1.5 \AA$. Newman (2004) and Thygesen et al. (2005) computed the crystallite width of cellulose and reported $30-34 \AA$ and $33,4 \pm 0,4 \AA$ respectively. The slight variation between these and the results from present study could be due to the slightly different material, growing conditions, age of the materials, experimental approach and the methods used.

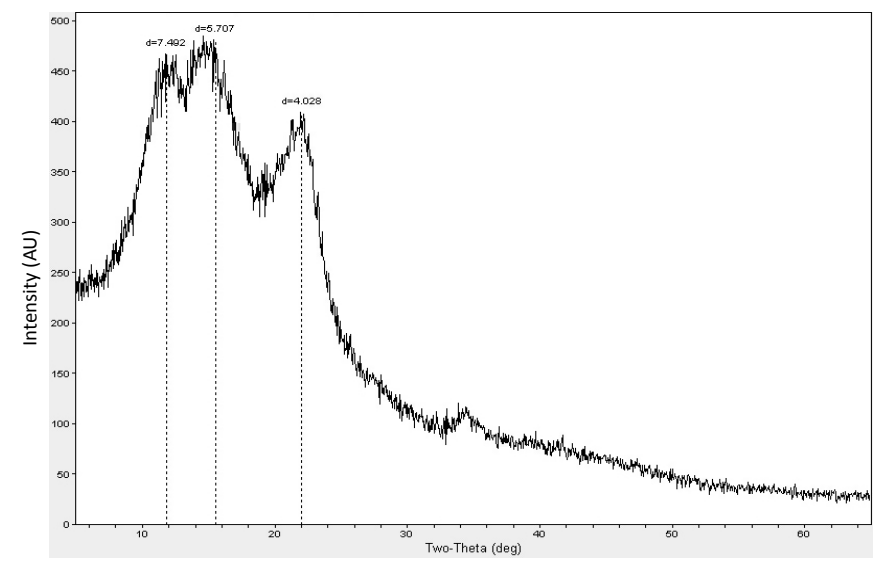

Figure 2. X-ray diffraction (XRD) spectra of Thuja burl wood powder. 
The small size Thuja burl wood specimens were kept in the conditioning room set at $21 \pm 2^{\circ} \mathrm{C}$ temperature and $60 \pm 5 \%$ relative humidity for a period of more than 60 days. As shown in Table 2, the average EMC value of Thuja burl wood was $10,19 \pm 1,43 \%$. This value is found to be slightly lower than the EMCs of wood $(12 \pm 2 \%)$ from different timber species and similar environmental conditions (FPL 1999). Mouridi et al. (2011b) and reported EMC of Thuja burr at $8 \%$ after drying under cover. Wood material is hygroscopic; it either absorbs or releases the moisture from/to the ambient environment depending on its own state of moisture content. Presence of $\mathrm{OH}$ groups in the chemical constituents is mainly responsible for the EMC of wood. At EMC, the inward flux of water molecules in the cell wall is exactly balanced by outward flux into the atmosphere. As EMC of Thuja burl wood is found to be slightly lower than other wood, this may consequently result into reduced water absorption, lower amount of shrinkage and swelling (better dimensional stability) and longer service life of wood. The decrease in EMC may be attributed to the reduction of accessible OH-groups as evidenced by slightly higher crystallinity index $(0,35)$ combined with the amount of oily extractives materials leading to a limited interaction with the water molecules.

Table 2. Average values of certain important physical properties of Thuja burl wood.

\begin{tabular}{|c|c|c|}
\hline \multicolumn{2}{|l|}{ Properties } & Measured Values \\
\hline \multicolumn{2}{|l|}{ Density $\left(\mathrm{kg} / \mathrm{m}^{3}\right)$} & $932,67 \pm 50,57$ \\
\hline \multicolumn{2}{|c|}{ Specific gravity (OD weight/volume at test) } & $863 \pm 46$ \\
\hline \multicolumn{2}{|c|}{ Equilibrium moisture content $(\%)$} & $10,19 \pm 1,43$ \\
\hline \multirow{2}{*}{$\begin{array}{c}\text { Total water } \\
\text { absorption (\%) }\end{array}$} & from dry state to 24 hours of immersion & $5,75 \pm 0,30$ \\
\hline & from oven-dry to 24 hours of immersion & $9,21 \pm 0,40$ \\
\hline \multirow{2}{*}{$\begin{array}{c}\text { Maximum } \\
\text { swelling (\%) }\end{array}$} & from dry state to 24 hours of immersion & $2,07 \pm 0,59$ \\
\hline & from oven-dry to 24 hours of immersion & $2,90 \pm 0,43$ \\
\hline
\end{tabular}

Table 2 lists the average value of the density of Thuja burl wood at EMC as $932,67 \pm 50,57 \mathrm{~kg} / \mathrm{m}^{3}$ which falls in the range of dense wood. The oven-dry specimens showed slightly lower density value of $891 \pm 49 \mathrm{~kg} / \mathrm{m}^{3}$ which was computed from the ratio of oven-dry weight to volume. The specific gravity was computed for Thuja burl wood and found to be $863 \pm 46$. The analysis of density measurements suggests the classification of Thuja wood burl wood as very dense to extremely dense species (Meier 2015). The higher density is often used as an indicator for the improved mechanical properties of wood. High density of burl wood may result from the presence of darker slow growth rings composed of cells with thicker walls and other tightly packed elements in the wood microstructure leading to lower porosity as observed under high resolution SEM. Mouridi et al. (2011a), Mouridi et al. (2011b) also reported dry density of Thuja burr close to $900 \mathrm{~kg} / \mathrm{m}^{3}$ which is in good agreement to values reported in the present study. These authors also classified Thuja root burr as a dense wood. The density of the root burl wood was found to be higher than that of the Thuja wood. This difference was attributed to the presence of numerous dark growth rings composed of cells with thicker walls compared to those of Thuja wood. El Alami et al. (2013) also studied the properties of wood as well as root burl wood of Tetraclinis articulata and found that thicker cell walls contributed to higher density of the burl wood than Thuja wood.

The amount of water absorption by the wood is mostly dependent on its porosity, microstructure, surface area, hydroxyl content, initial condition in terms of moisture content, seasoning method and duration period of soaking the specimen in water. Table 2 lists the average value of total water absorption after 24 hours of soaking at room temperature as $5,75 \pm 0,30 \%$ on conditioning air dry specimens and $9,21 \pm 0,40 \%$ on oven-dry state specimens. Figure 3 exhibits the water absorption profile in function of the soaking time of Thuja burl wood. After 2 hours water immersion, Thuja wood specimens water absorption is low at about $2 \%$. However, after 24 hours water immersion, Thuja wood specimens did not reach the fiber saturation point since the curve is still rising upward slowly with time. The water absorption rate of Thuja wood was found quite low compared to other wood species listed in the literature (Var and Oktem 1999, Khazaei 2008, Shukla and Kamdem 2010b). The slow water absorption profile suggests some likely good water repellency behaviour attributed to the microstructure with low porosity corresponding to high density, high cellulose crystallinity from low hemicellulose with high 
water retention capacity, amount of blocked cell lumens and presence of oily substances in the Thuja burl wood.

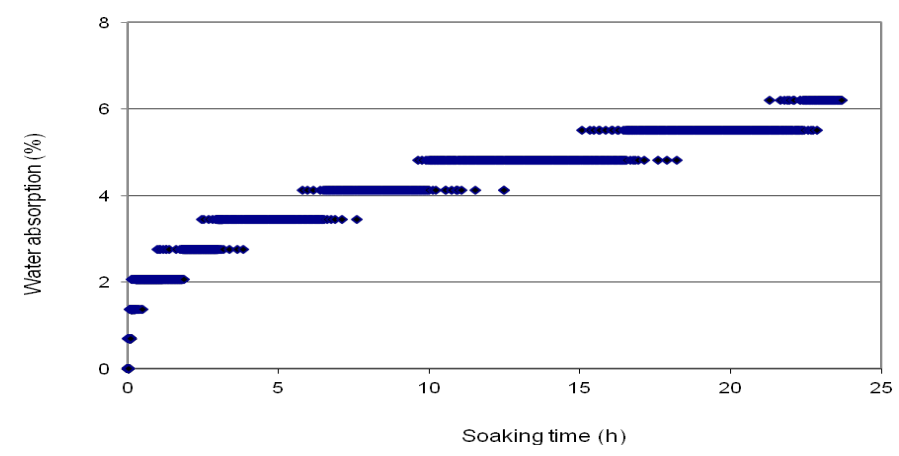

Figure 3. Real-time water absorption profile of conditioned Thuja burl wood block.

Table 2 shows swelling values of small burl wood specimens after 24 hours of water immersion as $2,07 \pm 0,59 \%$ and $2,90 \pm 0,43 \%$ depending on initial state - dry (conditioned) and oven-dry condition respectively. The anisotropy was computed from swelling values obtained from tangential and radial plane of specimens after 24 hours of water immersion and found to vary in the range from 1,07 to 1,11. The lower values of swelling anisotropy may be explained by random orientation of cells in the structure of Thuja burl wood. Shrinkage measurements carried out by Mouridi et al. (2011a) on Thuja burl wood also showed a very small anisotropy attributed to variable orientation of cells at microscopic scale. The mechanical behaviour of Thuja burl wood was also reported to be closer to be isotropic. Figure 4 depicts swelling profile of the ends of oven-dry Thuja burl wood specimen with water soaking time. The real-time swelling behaviour was found to follow curvilinear path. After 2 and 24 hours of immersion in water at room temperature, the swelling was about $0,6 \%$ and $2,1 \%$ respectively. The small swelling values clearly demonstrate the dimensional stability of Thuja burl which is one of the desirable property required by the items produced using this wood.

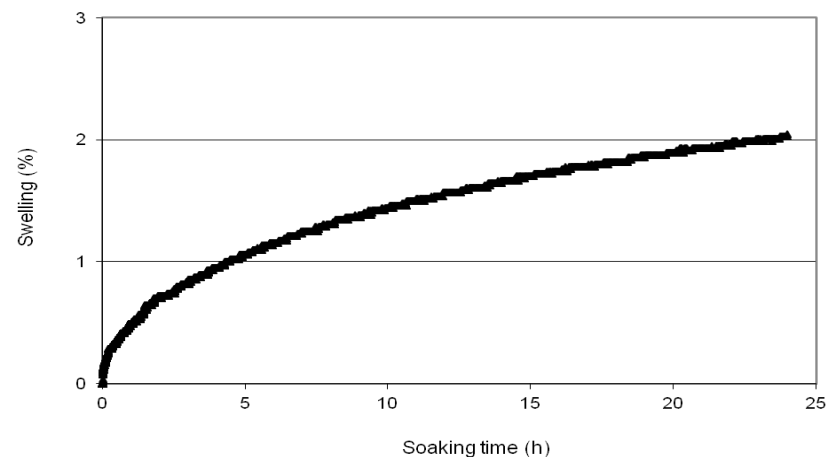

Figure 4. Real-time swelling profile of dry burl wood across ends with water soaking time. 


\section{CONCLUSIONS}

Microstructure and anatomical properties of Thuja burl wood were investigated using image analysis system, ESEM and XRD techniques. Certain important physical parameters such as EMC, density, specific gravity of Thuja burl wood along with real-time water absorption and swelling characteristics were evaluated. Thuja burl wood exhibited distinct dark brown, oily surfaces with pleasing aromatic smell. Microscopic observations showed very compact and thread-like fibers on the fractured surface. Thick walled tracheids with few blocked cell lumens were also observed. However, no resin canals could be found in Thuja burl wood. Average crystallinity index and diameter of crystallites computed from X-ray spectra were found to be $0,35 \pm 0,03$ and $36 \pm 5,58 \AA$. Average values of EMC and wood density were found to be $10,2 \pm 1,4 \%$ and $932,7 \pm 50,6 \mathrm{~kg} / \mathrm{m}^{3}$ respectively. Maximum swelling values of burl wood immersed in water for 24 hours from dry and oven-dry states were 2,07\% and 2,9\% respectively. Similarly, total water absorption varied from $5,8 \%$ to $9,2 \%$ depending on initial state of burl wood specimens. Overall, Thuja burl wood having higher density, dense microstructure, lower amount of swelling and water absorption (higher dimensional stability) render this wood as very much suitable for high-quality decorative and handicraft items.

\section{REFERENCES}

Andersson, S.; Serimaa, R.; Paakkari, T.; Saranppa, P.; Pesonen, E. 2003. Crystallinity of wood and the size of cellulose crystallites in Norway spruce (Pices abies). J Wood Sci 49: 531-537.

Andersson, S.; Wikberg, H.; Pesonen, E.; Maunu, S.L.; Serimaa, R. 2004. Studies of crystallinity of Scots pine and Norway spruce cellulose. Trees 18: 346-353.

American Society for Testing and Materials. ASTM. 2008. Standard test method for small clear specimens of timber. D 143-94 (Reapproved in 2000). West Conshohocken, PA (USA).

Beals, H.O.; Davis, T.C. 1977. Figure in wood- an illustrated review. Alabama Agricultural Experiment Station, Auburn University, Auburn Alabama, Bulletin No. 486, 5 pp.

Bouhtoury-Charrier, F.E.; Hakam, A.; Famiri, A.; Ziani, M.; Charrier, B. 2009. Wood characterization of Tetraclinis articulata and evaluation of its resistance against lignilolytic fungi. Doc No. IRG/WP 09-10697, Paper prepared for the 40 ${ }^{\text {th }}$ Annual Meeting, Beijing, China: 24-28 May, The International Research Group on Wood Protection, IRG Secretariat, Stockholm, Sweden.

El Alami, S.; El Mouridi, M.; Laurent, T.; Calchera, G.; Famiri, A.; Hakam, A.; Kabouchi, B.; Gril, J. 2013. Fracture energy of wood and root burl wood of thuya (Tetraclinis articulata). Journal of Tropical Forest Science 25(2): 166-174.

Esteban, L.G.; De Palacios, P.; Garcia-Iruela, A.; Roman-Jordán, E.; Garcia Fernandez, F.; Diaz, S.; Conde, M. 2015. Wood anatomy of Tetraclinis articulata from its natural distribution area in southeast Spain. IAWA Journal 36(1): 22-35.

FPL. 1999. Wood Handbook: Wood as an Engineering Material. Gen. Tech. Rep. FPL-GTR-113. Forest Product Laboratory, U.S. Department of Agriculture, Forest Service, Madison, WI (USA), 463 pp.

Hatimi, M. 1994. Approvisionnement du secteur artisanal en souches et bois de thuya dans la province d'Essaouira (SW du Maroc). Master thesis, Ecole Nationale Forestiere d'Ingenieurs, Sale, Morocco. 
Howell, C.; Hastrup, A.C.S.; Jellison, J. 2007. The use of x-ray diffraction for analyzing bio modification of crystalline cellulose by wood decay fungi. The International Research Group on Wood Preservation, $38^{\text {th }}$ Annual Meeting, 20-24 May, Wyoming (USA), IRG Secretariat, Stockholm, Sweden.

Ibaez, J.M.; Castanedo, J.L.; Santa, C.F.; Navarro, H.A.; Moreno, G.P. 1989. Data on a population of Tetraclinis articulata (Vahl) Masters. Ecologia 3: 99-106.

Kaiser, J. 1997. Thuya burl: The underground treasure. Wood \& Wood Products 102 (5): 1-4.

Khazaei, J. 2008. Water absorption characteristics of three wood varieties. Cercetări Agronomice in Moldova, Vol. XLI, No. 2 (134): 5-16.

Meier, E. 2015. Wood! Identifying and using hundreds of woods worldwide. Publisher: The Wood Database, pp 272, [Available] <http://www.wood-database.com/lumber-identification/softwoods/ thuya $>$ [Accessed 26 May 2017].

Mouridi, M. El; Laurent, T.; Famiri, A.; Kabouchi, B.; Almeras, T.; Calchera, G.; Abid, A.; EI Ziani, M.; Gril, J.; Hakam, A. 2011a. Physical characterization of the root burl wood of Thuja (Tetraclinis articulata (Vahl) Masters). Physical and Chemical News Journal 59: 57-64.

Mouridi, M. El; Laurent, T.; Brancheriau, L.; Arnould, O.; Famiri, A.; Abdelillah, H.; Gril, J. 2011b. Searching for material symmetries in the burr wood of Thuja by a direct contact ultrasonic method on spherical samples. Maderas-Cienc Tecnol 13(3): 285-296.

Moussaouiti, M. El; Talbaoui, A.; Gmouh, S.; Aberchane, M.; Benjouad, A.; Bakri, Y.; Kamdem, D.P. 2010. Chemical composition and bactericidal evaluation of essential oil of burl wood from Morocco. J Ind Acad Wood Sci 7(1-2): 14-18.

Navi, P.; Sandberg, D. 2012. Thermo-Hydro-Mechanical Processing of Wood. EPFL Press, CRC Press, Taylor and Francis Group, USA. Pp 360.

Newman, R.H. 2004. Homogeneity in cellulose crystallinity between samples of Pinus radiata wood. Holzforschung 58: 91-96.

Sanchez-Gomez, P.; Jimenez, J.F.; Vera, J.B.; Sanchez-Saorín, F.J.; Martinez, J.F.; Buhagiar, J. 2013. Genetic structure of Tetraclinis articulata, an endangered conifer of the western Mediterranean basin. Silva Fennica 45(5):14.

Segal, L.; Creely, J.J.; Martin, Jr A.E.; Conrad, C.M. 1959. An empirical method for estimating the degree of cystallinity of native cellulose using the X-ray diffractometer. Textile Research J 29(10): 786-794.

Shukla, S.R.; Kamdem, D.P. 2010a. Swelling of polyvinyl alcohol, melamine and urethane treated southern pine wood. Eur J Wood and Wood Products 68 (2): 161-165.

Shukla, S.R.; Kamdem, D.P. 2010b. Dimensional stability of nine tropical hardwoods from Cameroon. Journal of Tropical Forest Science 22(4): 389-396.

Thygesen, A.; Oddershede, J.; Lilholt, H.; Thomsen, A.B.; Stahl, K. 2005. On the determination of crystallinity and cellulose content in plant fibers. Cellulose 12(6): 563-576.

Var, A.A.; Oktem, E. 1999. Reduction by natural resin of water uptake in various wood species. Tr J of Agriculture and Forestry 23: 413-418.

Viiri, J.; Tyrväinen, H. 1999. A new method of measuring the water uptake of wood. Holz als Roh- und Werkstoff 57(3): 205-206.

Wellwood, R.W.; Sastry, C.B.R.; Micko, M.M.; Paszner, L. 1975. X-ray diffraction studies: A statistical evaluation of crystallinity index of Ramie by different methods. Mokuzai Gakkaishi 21(5): 272-277. 